\title{
REMOVAL OF HG(II) METAL IONS USING KAOLIN ADSORBENTS MODIFIED WITH ANIONIC SURFACTANT AND EFFICIENT ULTRASONIC ASSISTED
}

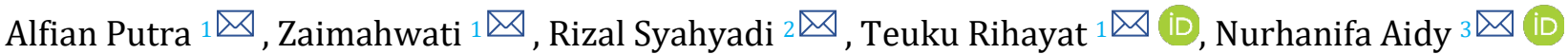 \\ ${ }^{1}$ Department of Chemical Engineering, PoliteknikNegeriLhokseumawe, Lhokseumawe, Aceh 24301, Indonesia. \\ ${ }^{2}$ Department of Civil Engineering, Politeknik Negeri Lhokseumawe, Banda Aceh-Medan Street, 280,3, \\ Buketrata, Mesjid Punteut, Blang Mangat, Lhokseumawe, Aceh 24301, Indonesia. \\ ${ }^{3}$ Departement of Renewable Energy, Universitas Malikussaleh, Tengku Nie, Cot Rd, Reuleut Tim., Muara Batu, \\ Kabupaten Aceh Utara, 24355, Aceh, Indonesia.
}

Received 10 October 2021

Accepted 01 November 2021

Published 30 November 2021

Corresponding Author

Alfian Putra,

alfianputra2021@gmail.com

DOI

10.29121/granthaalayah.v9.i11.2021 .4379

Funding: This research received no specific grant from any funding agency in the public, commercial, or not-for-profit sectors.

Copyright: (C) 2021 The Author(s). This is an open access article distributed under the terms of the Creative Commons Attribution License, which permits unrestricted use, distribution, and reproduction in any medium, provided the original author and source are credited.

\section{ABSTRACT}

This study reported the reduction of metal $\mathrm{Hg}$ (II) from water using natural kaolinite (NK) based adsorbents compared with modified kaolinite adsorbents with Hexadecyl trimethyl ammonium bromide anionic surfactants using ultrasonic technology (SMK). These adsorbent samples were characterized using several different techniques such as FTIR, X-RD and AAS analysis. The adsorption capacity is influenced by variables such as the contact time and adsorben dosage. The results of the analysis reported that the maximum waste reduction efficiency occurs in modified kaolin (SMK), where adsorption occurs faster than natural kaolin (NK). The maximum persentation is $94.57 \%$ for metal removal efficiency using modified kaolin at the contact time of 45 minutes and the dose of adsobene $1.4 \mathrm{~g}$, while kaolin without modification is $73.83 \%$ of efficiency at the contact time of 60 minutes the adsobent dose was $1.4 \mathrm{~g}$. The use of the adsorption method with the help of ultrasonic technology is proven to be more efficient in accelerating the removal of $\mathrm{Hg} 2+$ ions by increasing the surface dispersion of the adsorbent with metal ions in water. The adsorption kinetics model that is suitable for calculating the adsorption capacity of the adsorbent in the removal of $\mathrm{Hg} 2+$ ions using unmodified kaolin is pseudosecond-order models.

Keywords: Kaolinite, Adsrobent, Ultrasonic Assited, Surfactant, Removal of Metal

\section{INTRODUCTION}

Water pollution is a serious environmental problem that is important for the modern world today, water as an important for all activities of living things on earth, so water and wastewater treatment is a global concern. Awale and Soubaneh (2014), Mahmoodi and Oveisi (2019) Since the industrial revolution in the 18th century, a large increase in industrial activities including metals, dye, battery, printing, mining, engineering metallurgy, electroplating, pigment, PVC stabilizers, electrical equipment manufacturing, semiconductors, and cosmetics produce various types of pollutants in liquid waste which dispose of byproducts in lakes, oceans and rivers, which pollutes water. Mahmoodi (2014).

The largest market share and growth in the Adsorbent Market and is anticipated to reach $\$ 2.3$ billion by 2023 at a CAGR of $7.7 \%$. The escalating population in the Asia-Pacific region has triggered the need for different petrochemical and petroleum products that are one of the key drivers for the 
adsorbent market. Vietnam, Myanmar and Indonesia are the emerging markets for the adsorbent market as these nations have a developing petroleum industry and comprises of many such plants scheduled to come in the coming years. The key end user markets in the Asia Pacific region are oil refineries, natural gas refineries, waste water treatment plants, refrigeration and air conditioning systems and others. Japan, China, Australia, India and South East nations are the leading manufacturing hubs.

Raw materials such as peat, wood, coir, lignite, coal, coconut, silicate, bauxite and others are procured and further processed by physical and chemical processes. The physical process involves activation processes in the absence of oxygen, and the chemical process involves the treatment of the raw material with an acid or base. By using organic matter as raw materials such as sewage sludge and the remains of plants or animals and others, adsorbents can be manufactured.
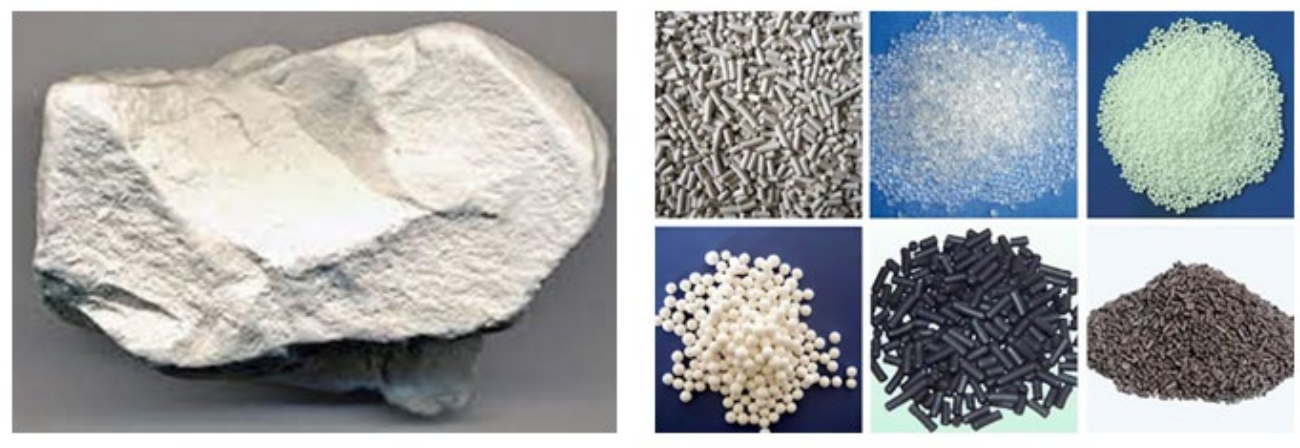

Figure 1 Several Kinds of Adsorbents Mahmoodi and Oveisi (2019)

Heavy metals are hazardous pollutants because they are not degraded, are persistent, accumulative and have high and high toxic effects even at low doses so that they can cause damage to human health as well as to the universal ecological system. Kashi (2017) Heavy metals are included in the main group of inorganic polluting materials and pollute large areas of land due to their presence in fertilizer, municipal waste, pesticides, mining industry and smelting. Ariffin et al. (2017) It can be removed by using several conventional methods such as membrane chemical precipitation, filtration, coagulation, chemical extraction, ion exchange etc. However, this conventional technique has several disadvantages such as high energy requirements, sensitive operating conditions and low efficiency. Tripathi and Ranjan (2015)

Table 1 MCL standard and ill effect of hazardus heavy metals. Singh and Gupta (2016)

\begin{tabular}{ccc} 
Heavy Metal & Ill Effect & MCL, mg/L \\
\hline As & Skin and vascular diseases, visceral cancer & 0.05 \\
\hline $\mathbf{C r}$ & Headache, Diarrhea, Nausea, Carsiogemic & 0.05 \\
$\mathbf{H g}$ & Rheumatoid arthritis, circulatoru \& Nervous disorder & $3.0 \times 10-5$ \\
\hline $\mathbf{C u}$ & Liver damage, Insomnia, Wilson's disease & 0.25 \\
\hline $\mathbf{C d}$ & Renal disorders and damage, Carsiogenic & 0.01 \\
$\mathbf{N i}$ & Dermatitis, Chronic, Asthma, Carsiogenic & 0.20 \\
$\mathbf{P b}$ & Renal, Cerebal Disorder, Nervous disorder \& Circulatory & $6.0 \times 10-5$
\end{tabular}

To overcome this weakness, the adsorption method is considered to be one of the most economical and efficient processes in removing harmful metal ions, due to 
its availability, low cost and operation. Leal et al. (2017), Santhosh et al. (2016) This process involves separating a substance from one phase and accumulating it on another surface. This methode is effective in removing toxic pollutants, even at low concentrations and is easy to operate. Rao et al. (2014) Adsorption is often accompanied by an inversion-desorption process, which represents the transfer of adsorbate ions to solution from the adsorbent surface. The adsorption reversibility can depend on the amount of adsorbate adsorbed from the adsorbent, the more adsorbate is adsorbed, the more reversible the adsorption process. Rao et al. (2014), Mishra (2014) Kaolin is one of the adsorbents that is often used in the metal ion adsorption process.

Kaolin is a fine particle composed of one layer of tetrahedral oxygen silicate (SiO4) and one layer of octahedral alumina in a ratio of 1: 1. Kaolin has low expansion, high chemical stability and cation exchange capacity. Kaolin is classified into trioctahedral and dioctahedral minerals. Kaolin has the potential to be an adsorbent because it is cheap, safe, and easy to obtain, which is available throughout the world in rock as a crystalline structure. Emam et al. (2017), Mustapha et al. (2019) However, the absorption ability of kaolin as an adsorbent is still low when compared to zeolites, activated charcoal, and bentonite. Teuku et al. (2019) It has to be an effort to increase the ability of adsorption of kaolin, which is by using surfactant as agent to modification.

The weathering process in the formation of kaolin occurs at or near the soil surface which mostly occurs in igneous rocks. Meanwhile, the hydrothermal alteration process occurs because the hydrothermal solution flows through fractures, faults, and other permeable areas while converting limestone into kaolin deposits. Safitri et al. (2020), Mudzielwana et al. (2019), Sodeifian and Ali (2018) Kaolin deposits consist of two kinds, namely residual and sediment. Residual kaolin, this type is found where it was formed with the parent rock, has not undergone displacement, crystals are regular, and ion substitution is rare. Kaolin sedimentary, has undergone displacement by water, wind, glaciers, deposited in basins, and irregular crystals. The structure of kaolin can be seen in Figure 2.

The surface of the kaolinite crystal has a constant negative charge and does not depend on $\mathrm{pH}$ (permanent charge). The negative charge comes from atomic substitution in the crystal structure which does not affect the crystal structure, for example, the presence of an $\mathrm{Al}$ atom with a charge of +3 replacing a $\mathrm{Si}$ atom with a charge of ${ }^{+4}$ causes the kaolinite framework to lack a positive charge or an excess of negative charge. Sodeifian and Ali (2018)

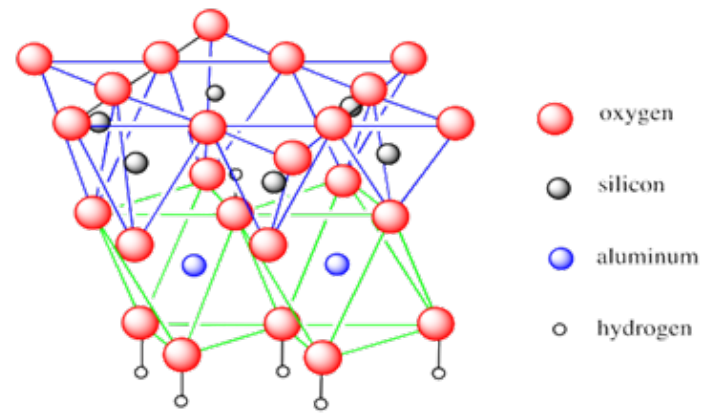

Figure 2 Kaolinite structure Coelho et al. (2014)

This modification increases the absorption of anions through ion exchange. Based on research Leal et al. (2017), natural kaolin was successfully modified through the intercalation of the surfactant Hexadecyltriammonium bromide (HDTMA-Br) to the interlayers. The adsorbents modified showed a maximum 
adsorption capacity of 2.3 and $2.88 \mathrm{~m} 2 / \mathrm{g}$. This means that the aid of ultrasonic technology can significantly improve the adsorption ability of the adsorbent. Ultrasonic has proven to be a very useful tool in severing the relationship between adsorbents and adsorbates and intensifying the process of mass transferc. Mudzielwana et al. (2019), Sodeifian and Ali (2018)

Ultrasonic technology has the advantage of being low in operating costs and has no negative impact on the environment. This technique has the effect of increasing the absorption capacity of the adsorbent up to two times with the help of ultrasonic speed which in the process increases the surface area of the adsorbent. Roosta et al. (2017) This research focused in investigation and study of optimization of kaolinite adsorbent by modifying with hexadecyltrimethylammonium (HDTMA) surfactants and ultasonic irradiation in adsorbing Hg (II) metal in water. It is hoped that the ultrasonic technology can become one of the environmentally friendly alternatives in an effort to increase adsorbent absorption, especially kaolin.

\section{MATERIALS AND METHODS 2.1. MATERIAL AND METHODS \\ 2.1.1. MATERIALS}

Natural kaolin is collected from Nisam, North Aceh. Natural kaolin is activated using $1 \mathrm{~N} \mathrm{HCl}$ for one hour, then washed and dried in an oven at $85{ }^{\circ} \mathrm{C}$, filtered through a 110-mesh filter and then stored in a desiccator before use. All chemicals used in this study are analytical reagent class. The surfactant used is hexadecyltrimethylammonium (HDTMA) purchased from Merck. The metals and $\mathrm{HCl}$ used in this study were purchased from Rudang Jaya, North Sumatra.

\subsection{METHODS}

\subsubsection{SYNTHESIS OF SURFACTANT MODIFIED KAOLIN CLAY (SMK)}

To synthesize a modified kaolin surfactant, activated kaolin is added $10 \mathrm{~g}$ to a hexadecyltrimethylammonium (HDTMA) $(50 \mathrm{~mL})$ surfactant solution known and the mixture is maintained in a shaker incubator at $30{ }^{\circ} \mathrm{C}$ and $150 \mathrm{rpm}$ for 24 hours. The residue is washed with distilled water several times to remove excess surfactants. The residue obtained was then dried in an oven at $60{ }^{\circ} \mathrm{C}$ for 12 hours and then ground using mortar and pestle to pass through a 110-mesh sieve. The experiment was repeated until adequate adsorbents were synthesized. Suryani et al. (2020)

\subsubsection{CHARACTERIZATION OF SAMPLES}

The physicochemical properties of the sample are determined by X-ray diffraction (XRD), Fourier transform infrared spectroscopy (FT-IR), and AAS. Shimadzu-8400S spectrometer was used for recorded of spectrum in the range of 400-4000 cm-1 at room temperature using KBr pellets. Raya and Zakir (2014) X-ray diffraction pattern recorded by the STOE powder diffraction system using CuK radiation with wavelength of $1.54060 \AA$. The level of $\mathrm{Hg}^{2+}$ ions is determined by the Shimadzu AAS model AA-6300. The $\mathrm{pH}$ is measured using a $\mathrm{pH}$ meter. Ultrasonic bath with heating system (Elmasonic, Italy) at a frequency of $60 \mathrm{~Hz}$ and a power of $130 \mathrm{~W}$ is used for ultrasound-assisted adsorption procedures. The adsorption of metal ions $\mathrm{Hg}$ (II) from water with modified kaolin using ultrasonic technique was studied to find the optimal adsorbent dose, $\mathrm{pH}$ and sonication time as well as initial 
$\mathrm{Hg} 2+$ concentration. The solution containing the metal ion $\mathrm{Hg}^{2+}$ was mixed with natural kaolin and modified kaolin adsorbent at a certain $\mathrm{pH}$ (adjusted with acetate buffer) in an ultrasonic bath for a variable time. Then the adsorbent was immediately separated from the solution and the remaining $\mathrm{Hg}^{2+}$ ion concentration was measured by atomic absorption spectrophotometer. Mathematically the number of $\mathrm{Hg}^{2+}$ ions adsorbed at equilibrium conditions (Qe, mg g-1) is obtained by using Equation (1):

$$
Q e=\frac{(\mathrm{Co}-\mathrm{Ce}) \mathrm{V}}{M}
$$

Where, Co, Ce is the initial concentration and equilibrium of $\mathrm{Hg}$ (II) (mg L-1), and $\mathrm{V}$ and $\mathrm{M}$ are the volume of solution ( $\mathrm{ml}$ ) and mass of adsorbent ( $\mathrm{g}$ ). Jeeva et al. (2019)

\section{RESULTS AND DISCUSSIONS}

\subsection{CHARACTERIZATION OF KAOLINITE ADSORBENT}

The FTIR spectrum of the material was used to determine the composition and pattern of functional groups. The FTIR spectrum of natural kaolin (NK) and kaolin modified surfactant (SMK) is presented in Figure 3. For NK, the absorption band at $3663.23 \mathrm{~cm}^{-1}$ and $1626.17 \mathrm{~cm}^{-1}$ shows the $-\mathrm{OH}$ stretching vibration in water adsorbed by physis. Bands at $1012.50 \mathrm{~cm}-1$ and $961.54 \mathrm{~cm}^{-1}$ were associated with vibrations of Si-OH and Al-OH bonds. The band at $1509.46 \mathrm{~cm}^{-1}$ shows the vibrations of the $\mathrm{C}-\mathrm{C}-\mathrm{C}$ flex vibrations associated with the methylene group. Bands at lower wavelengths indicate $\mathrm{Al}-\mathrm{O}-\mathrm{Si}$ and $\mathrm{Si}-\mathrm{O}-\mathrm{Si}$ network vibrations.

Hexadecyl trimethyl ammonium bromide (HDMTA) spectrum indicated stronger absorption bands in the region of 2893.51 and $2944.05 \mathrm{~cm}^{-1}$, which are assigned to the $\mathrm{C}-\mathrm{H}$ stretching bond in the - $\mathrm{CH} 3$ and $-\mathrm{CH} 2$ groups. Bands at 925.72 $\mathrm{cm}-1$ and $946.4 \mathrm{~cm}^{-1}$ are associated with vibrations of $\mathrm{C}-\mathrm{N}$ bonds. It was confirmed by bands at 2847.25 and $2975.31 \mathrm{~cm}-1$ that kaolinite adsorbent succefully modified which were ascribed to the vibrations of the $\mathrm{C}-\mathrm{H}$ bond. After mercury adsorption, no changes were observed in the modified kaolin spectrum. However, there is an increase in the intensity of the band transmittance. This could be an indication that $\mathrm{Hg}$ (II) can produce a higher adsorption affinity for contaminants. Ridwan et al. (2018)

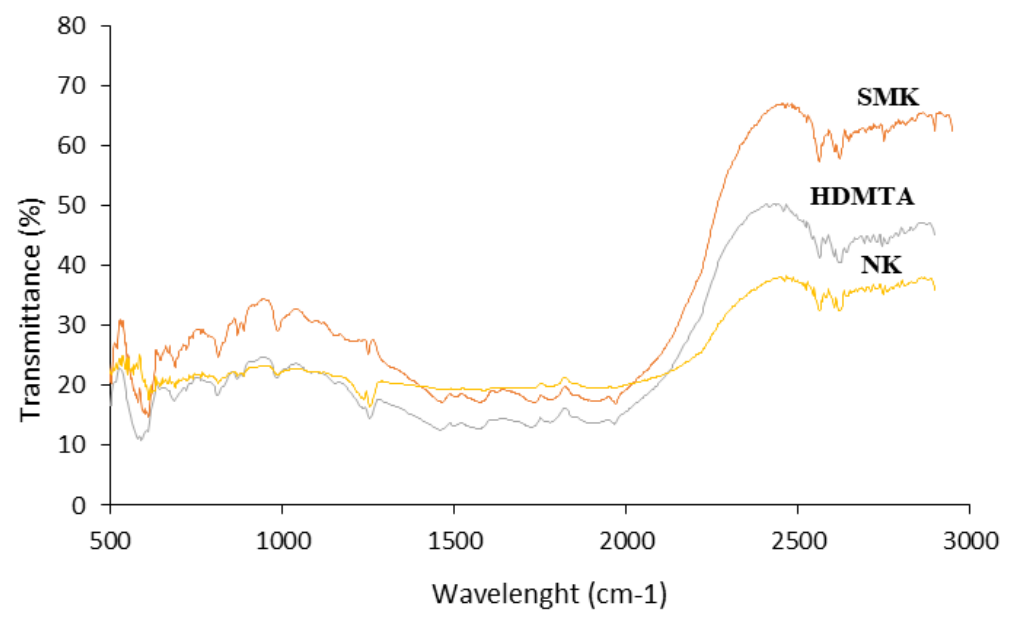

Figure 3 FTIR spectrum of NK, HDTMA and SMK 
The crystal structure a purity of the prepared sample is determined by X-ray diffraction analysis. In Figure 4. presents the XRD pattern of natural kaolin (NK) and modified kaolin with surfactant (SMK). The results reported that the main kaolinite consisted of quartz and kaolin as the main minerals. After modification with HDTMA, no changes were observed in the kaolin XRD pattern. This could indicate that the absorption of HDTMA surfactants to the surface of the kaolin mineral does not affect the clay layer. The same observation was also reported by Wu et al. (2015), during the modification of bentonite clay using hexadecyltrimethylamonium chloride.

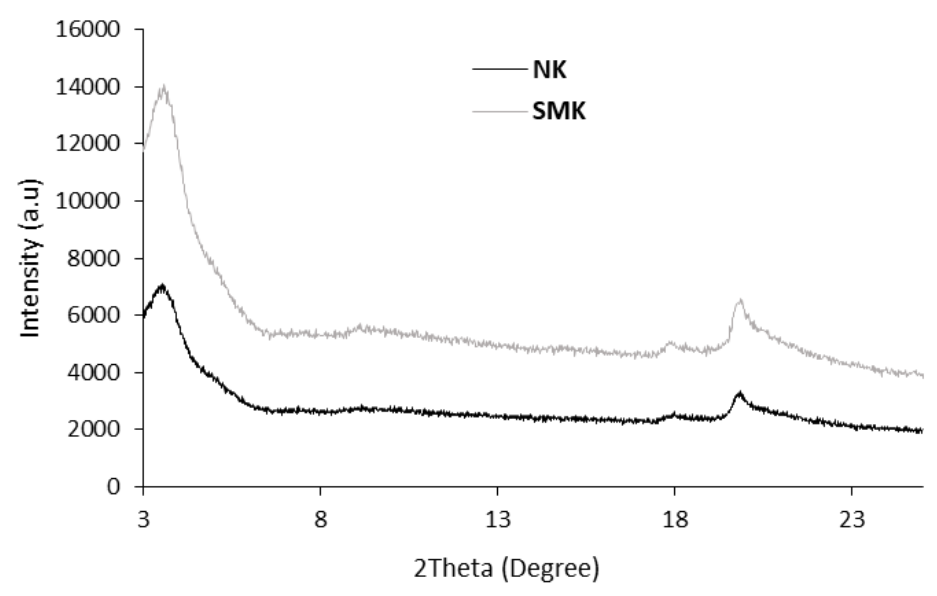

Figure 4 XRD pattern (Quartz) of NK and HMK

\subsection{EFFECT OF CONTACT TIME}

A batch experiment was carried out to investigate the adsorption efficiency and ultrasonic-assisted adsorption process to remove $\mathrm{Hg}$ ions. The contact time needed to effectively remove metal by the adsorbent is important to determine when the equilibrium time is reached. The effect of contact time on metal adsorption to kaolin clay SMK and NK is shown in Figure 4. The results showed a very significant difference between the adsorbent SMK and NK adsorbents, SMK was more efficient in adsorbing $\mathrm{Hg}^{2+}$ than in $\mathrm{NK}$ adsorbents.

The adsorption efficiency of NK results obtained the best results at 60 minutes contact time by $73.83 \%$, while at SMK the best results at 45 minutes contact time were $94.57 \%$. This is because the $\mathrm{Hg}^{2+}$ has been adsorbed in the pores of SMK adsorbents because of the molecules in wastewater that move faster, so interactions between SMK adsorbents and metal ions occur more frequently, the longer the ultasonic contact time the absorption efficiency decreases due by the saturation of the adsorbent in adsorbing the metal $\mathrm{Hg}^{2+}$. Sun et al. (2015) 


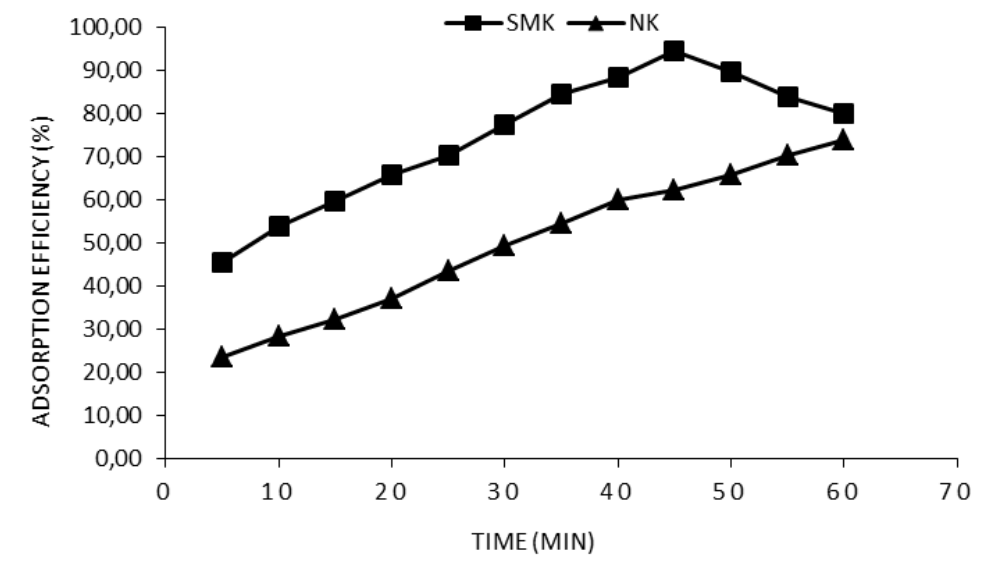

Figure 5 Effect of contact times on the adsorption of $\mathrm{Hg}^{2+}$ on SMK and $\mathrm{NK}$.

The mechanism for increasing the adsorption of kaolin adsorbents with the addition of surfactants is because it attaches to the kaolin surface forming interactions between molecules on the kaolin and surfactants. Interaction causes the formation of a new layer, thus forming a collection of bilayers which results in many metal ions being adsorbed. In addition, the presence of surfactants also increases the number of ions that are on the surface of the surfactant, so that more modified adsorbents capture the ions around them in wastewater. Lee et al. (2015)

According to research conducted by Fainerman et al. (2020), adsorbing Cr (IV) metal using anionic surfactant modified kaolin and obtaining an absorption efficiency of $95.08 \%$ at an optimal contact time of 180 minutes, The difference in optimal absorption time that occurs due to absorption using ultrasonic can adsorb metals quickly because the effect of using high-speed ultrasonic techniques in the adsorption process increases the surface area. This accelerates the movement of molecules so that the adsorption process occurs faster. Suryani et al. (2018) This phenomenon is caused by cavitation (nucleation, growth, and collapse of small gas bubbles) and high-pressure variations induced during ultrasonic irradiation. Soltani et al. (2016)

\subsection{EFFECT OF ADSORBENT DOSAGE}

The effect of the adsorbent dose was investigated by experimenting on adsorbent doses that differed from 0.4 to $1.4 \mathrm{~g} / \mathrm{L}$ at $\mathrm{pH} 8$ and an initial concentration of $50 \mathrm{mg} / \mathrm{l}$. Figure 6 . Shows an increase in the amount of adsorbent in adsorbing $\mathrm{Hg}^{2+}$ in SMK and NK. At lower doses, the adsorption rate is influenced by competition between ions among metal ions caused by the presence of a small surface area. At higher doses, the adsorption process in NK and SMK increases. This is due to the increased availability of active binding sites and a greater surface area of the adsorbent. Thus, this affects the removal efficiency of the $\mathrm{Hg}^{2+}$ metal from the solution by the adsorbent. This can also be concluded because of the availability of sites which can be exchanged for adsorption. Saleh et al. (2016), Haroon (2016) 


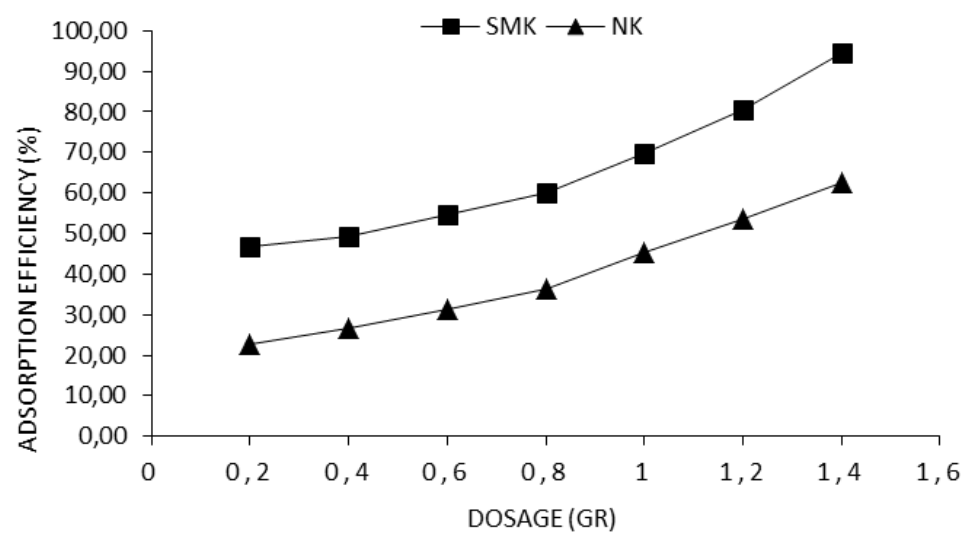

Figure 6 Effect of dosage on the adsorption of $\mathrm{Hg}^{2+}$ on SMK and NK.

\subsection{ADSORPTION KINETIC STUDY}

Examination of reaction kinetics is an important factor in the design of adsorption systems. The adsorption process will depend on the condition of the system and the physical or chemical characteristics of the adsorbent system. Both the first and second pseudo models were investigated to study the rate and mechanism of the adsorption process. Zhou et al. (2018) In 1898, for the first time, Lagergren had proposed a pseudo-first order model. Vargas et al. (2011) The pseudo-first and pseudo-second sequence models are applied to check the adsorption rate based on equilibrium time data. Vargas et al. (2011) The secondorder pseudo-kinetic model can anticipate adsorption behavior in the entire adsorption range. Intra-particle diffusion models are mostly applied to distinguish pathways and mechanisms as well as the driving forces involved in adsorption. Vargas et al. (2011)

Table 2 Constant parameters for pseudo-first-order and pseudo-second-order models of reaction kinetics (initial concentration of $5 \mathrm{mg} / \mathrm{L}$, adsorbent dosage of $1.4 \mathrm{~g}$ )

\begin{tabular}{lllll}
\hline Model & Equation & Parameter & \multicolumn{2}{c}{ Value of parameter } \\
& & & SMK & NK \\
First-order & $\mathrm{Log}(\mathrm{qe}-\mathrm{qt})=\log (\mathrm{qe})-$ & $\mathrm{k}_{1}$ & 1.879 & 1.067 \\
kinectic & $\mathrm{k} 1 / 2.303 \mathrm{t}$ & $\mathrm{qe}(\mathrm{calc})$ & 142.87 & 128.56 \\
& & $\mathrm{R}^{2}$ & 0.8921 & 0.8364 \\
Second-order & $\mathrm{(t} / \mathrm{qt})=1 /(\mathrm{k} 2 \mathrm{qe} 2)+1 / \mathrm{qe}(\mathrm{t})$ & $\mathrm{K}_{2}$ & 0.052 & 0.023 \\
kinectic & & $\mathrm{qe}($ calc $)$ & 142.65 & 132.44 \\
& & $\mathrm{R}^{2}$ & 0.9994 & 0.9921
\end{tabular}

Apart from the first-order model, the plot of $t / q t$ vs $t$ for the second-order kinetic model gives a straight line with a high correlation coefficient which is $\mathrm{k} 2$ and the equilibrium adsorption capacity (qe) is calculated from the intercept and slope of this line, respectively. The value of $\mathrm{R}^{2}$ and the proximity of experimental and theoretical adsorption capacity values (qe) indicate the application of a secondorder model to explain and interpret experimental data. The $\mathrm{R}^{2}$ value for the secondorder pseudo-kinetic model was found to be higher, namely for SMK 0.9994 and for NK which was 0.9921 and the qe value calculated was especially close to the experimental adsorption capacity value under different physicochemical conditions. 


\section{CONCLUSIONS AND RECOMMENDATIONS}

In this study, the natural kaolin clay mineral (NK) was successfully modified through the intercalation of HDTMA surfactant (SMK) to interlayers and ultrasonic assistance to remove $\mathrm{Hg}^{2+}$ metal ions in water. The synthesized adsorbents showed the maximum adsorption efficiency of SMK and NK $94.57 \%$ and $73.57 \%$, respectively. In this study it was also proven that the ultrasonic adsorption method became a very useful tool in intensifying the mass transfer process and severing the relationship between adsorbate and adsorbent. For the sake of comparison, ultrasonic adsorption is higher and faster than the adsorption process. Also, kinetic studies show that the adsorption process follows the pseudo-second order.

\section{ACKNOWLEDGEMENTS}

The authors express their gratitude and thanks to the Education, Culture, Research and Technology Ministry of the Republic of Indonesia for the financial support through grant Nomor: 256/E4.1/AK.04.PT/2021.

\section{REFERENCES}

A. Gil, L. Santamaría, S.A. Korili, M.A. Vicente, L.V. Barbosa, S.D. de Souza, L. Marçal, E.H. de Faria, K.J. Ciuffi, (2021) A review of organic-inorganic hybrid clay based adsorbents for contaminants removal: Synthesis, perspectives and applications. Journal of Environmental Chemical Engineering. 9, 105808. Retrieved from https://doi.org/10.1016/j.jece.2021.105808

A. Vargas, A. Cazetta, M. Kumita, T. Silva, V. Almeida. (2011) Adsorption of methylene blue on activated carbon produced from flamboyant pods \{(D\}elonix regia): study of adsorption isotherms and kinetc models. Chem. Eng. J. 168, 722730. Retrieved from https://doi.org/10.1016/j.cej.2011.01.067

Ana Vera de Toledo Piza Figueiredo Ferreira, Lorrana Vietro Barbosa, Suelen Delfino de Souza, Katia Jorge Ciuffi, Miguel Angel Vicente, Raquel Trujillano, Sophia A. Korili, Antonio Gil, Emerson Henrique de Faria. (2021) Titaniatriethanolamine-kaolinite nanocomposites as adsorbents and photocatalysts of herbicides. Journal of Photochemistry and Photobiology A: Chemistry. 419, 113483. Retrieved from https://doi.org/10.1016/j.jphotochem.2021.113483

Anais Adauto, María R. Sun-Kou. (2021) Comparative study of anion removal using adsorbents prepared from a homoionic clay. Environmental Nanotechnology, Monitoring \& Management. 15, 100476. Retrieved from https://doi.org/10.1016/j.enmm.2021.100476

Anirudhan, T. S., \& Ramachandran, M. (2015) Adsorptive removal of basic dyes from aqueous solutions by surfactant modified bentonite clay (organoclay): Kinetic and competitive adsorption isotherm. Process Safety and Environmental Protection, 95, 215-225. Retrieved from https://doi.org/10.1016/j.psep.2015.03.003

Ariffin, N., Abdullah, M.M.A.B., Mohd Arif Zainol, M.R.R., Murshed, M.F., Zain, H., Faris, M.A., Bayuaji, R. (2017) Review on adsorption of heavy metal in wastewater by using geopolymer. MATEC Web Conf., 97, 01023. Retrieved from https://doi.org/10.1051/matecconf/20179701023

Awale h, M.O., Soubaneh , Y.D, (2014) Waste water treatment in chemical industries: the concept and current technologies. Hydrol. Curr. Res., 5, 164 - 175. 
https://d1wqtxts1xzle7.cloudfront.net/63755884/Waste_Water_Treatme nt_in_Chemical_Indust20200627-112604-o7bmhs-with-cover-pagev2.pdf?Expires $=1637758347 \&$ Signature $=$ eyy5RpXbmV5rtVtops9yGXwLNP 1U MrmsVizx nXwI0DfjW1 fnXxK92pIm1t4HUAqagATII0yXm5M3uzhq 7Fw8d7nBA0mXa2A8X7Ekbb0 MOW9OfAmDELOTvF34t0acYHjSQ8nrBAOCMEqa5HPj-X93-5F0Nf49ZSsuDiLwaPIGN4kKb9LT008kwSIW5z17e6thF0jtTrtZXWVP3zTI F IYBkv-

EJlkNjaPTS7FPwRk4yYgBdS4yIUloAAx5qinf5NDcP 5JLRh48PY12bbWrb p p370HZLm0ZlxdU7SkSRMCsiOBNnuZHTsyOgCNnaDigXU4JPmAs5Cwkit 91g_\&Key-Pair-Id=APKAJLOHF5GGSLRBV4ZA

Bamidele I. Olu-Owolabi, Paul N. (2021) Diagboya, Fanyana M. Mtunzi, RolfAlexander Düring. Utilizing eco-friendly kaolinite-biochar composite adsorbent for removal of ivermectin in aqueous media. Journal of Environmental Management, 279, 111619. Retrieved from https://doi.org/10.1016/j.jenvman.2020.111619

Coelho, G.F., Goncalves Jr., A.C., Tarley, C.R.T., Casarin, J., Nacke, H., Francziskowski, M.A., (2014) Removal of metal ions Cd (II), Pb (II), and Cr (III) from water by the cashew nut shell Anacardium occidentale. Ecol. Eng. 73, 514 -525. Retrieved from https://doi.org/10.1016/j.ecoleng.2014.09.103

Diana Guaya, Rocío Jiménez, Janeth Sarango, César Valderrama, José Luis Cortina. (2021) Iron-doped natural clays: Low-cost inorganic adsorbents for phosphate recovering from simulated urban treated wastewater. Journal of Water Process Engineering, 43, 102274. Retrieved from https://doi.org/10.1016/j.jwpe.2021.102274

Emam, A. A, L.F.M. Ismail, M.A. AbdelKhalek, AzzaRehan. (2017) Adsorption Study of Some Heavy Metal Ions on Modified Kaolinite Clay. International Journal Of Advancement In Engineering Technology, 3, 152-163. https://d1wqtxts1xzle7.cloudfront.net/47881660/IJ16M0784-with-coverpage-

v2.pdf?Expires $=1637758760 \&$ Signature $=$ QaUJ76GIzSTEcUvRht1zFWtiQZ weA75ABS6 YRG-8rBpndNcwv-2h8TBeyzXUdpQQ05Mbiqb00-

MzB M7oqdS9TQ3siTSAmoSKc4ic8sW cmZOfLoZ6T9LQBFmFmUYBkYR JhYcpFQig5J6omBZLW42upGffx5oUnmazAfHdKcTyGYQ4XaWEp9YHfq9CpViuTdCvy1QD7goNZC9J2Go4ebIm8 1zEn 2NtkvFOsI0G0yR7kwrkI UE9ryiGK8UR1 iX8SW3YcsLx 7tuRRXVoljc0wfU-

WS3 I94yhhiM9p1PvY0l3TD5ruceBnoFxmfO9z6Nqc yUr9WFmD3NXsPJ g_\&Key-Pair-Id=APKAJLOHF5GGSLRBV4ZA

Fainerman, V. B., Aksenenko, E. V., Kovalchuk, V. I., Mucic, N., Javadi, A., Liggieri, L., Schneck, E. (2020) New view of the adsorption of surfactants at water/alkane interfaces - Competitive and cooperative effects of surfactant and alkane molecules. Advances in Colloid and Interface Science. 279, 102143. Retrieved from https://doi.org/10.1016/j.cis.2020.102143

G. Zhou, J. Luo, C. Liu, L. Chu, J. (2018) Crittenden. Efficient heavy metal removal from industrial melting effluent using fixed-bed process based on porous hydrogel adsorbents. Water Res. 131, 246-254. Retrieved from https://doi.org/10.1016/j.watres.2017.12.067

Gupta, V.K., Tyagi, I., Agarwal, S., Moradi, O., Sadegh, H., Shahryari-Ghoshekandi, R.,Makhlouf, A.S.H., Goodarzi, M., Garshasbi, A. (2016) Study on the removal of heavy metal ions from industry waste by carbon nanotubes: effect of the 
surface modifi cation - a review. Critic. Rev. Environ. Sci. Technol. 46, 93118. Retrieved from https://doi.org/10.1080/10643389.2015.1061874

H. Haroon, T. Ashfaq, S.M.H. Gardazi, T.A. Sherazi, M. Ali, N. Rashid, M. Bilal. (2016) Equilibrium kinetic and thermodynamic studies of $\mathrm{Cr}$ (VI) adsorption onto a novel adsorbent of Eucalyptus camaldulensis waste: batch and column reactors. Korean J. Chem. Eng. 33, 2898-2907. Retrieved from https://doi.org/10.1007/s11814-016-0160-0

Huan Zhang, Qingdong He, Wenting Zhao, Fang Guo, Lei Han, Wenbo Wang. (2021) Superior dyes removal by a recyclable magnetic silicate@Fe304 adsorbent synthesized from abundant natural mixed clay. Chemical Engineering Research and Design. 175, 272-282. Retrieved from https://doi.org/10.1016/j.cherd.2021.09.017

Jeeva, M., Lakkaboyana, S. K., \& WY, W. Z. (2019) The adsorption of Direct Brown 1 dye using kaolinite and surfactant modified kaolinite. Bulletin of the Geological Society of Malaysia,, 67, 35-45. Retrieved from https://doi.org/10.7186/bgsm67201905

L. Mouni, L. Belkhiri, J. C. Bollinger, A. Bouzaza, A. Assadi, A. Tirri, H. Remini. (2018) Removal of Methylene Blue from aqueous solutions by adsorption on Kaolin: Kinetic and equilibrium studies. Appl. Clay Sci. 153, 38-45. Retrieved from https://doi.org/10.1016/j.clay.2017.11.034

Leal, P. V., Magriotis, Z. M., Sales, P. F., Papini, R. M., Viana, P. R. (2017) Effect of the acid treatment conditions of kaolinite on etheramine adsorption: A comparative analysis using chemome tric tools. Journal of Environmental Management. 197, 393-403. Retrieved from https://doi.org/10.1016/j.jenvman.2017.04.003

Lee, S.M., Lalmunsama, Thanhimngliana, Tiwari, D. (2015) Porous hybrid materials in theremediation of water contaminated with $\mathrm{As}(\mathrm{III})$ and $\mathrm{As}(\mathrm{V})$. Chem. Eng. J. 270, 496-507. Retrieved from https://doi.org/10.1016/j.cej.2015.02.053

M. Ayisha Sidiqua, V.S. Pria. (2021) Removal of yellow dye using composite binded adsorbent developed using natural clay and activated carbon from sapindus seed. Biocatalysis and Agricultural Biotechnology, 33, 101965. Retrieved from https://doi.org/10.1016/j.bcab.2021.101965

Mishra, S.P., (2014) Adsorption-desorption of heavy metal ions. Curr. Sci. India. 107, 601 -612. Retrieved from https://www.jstor.org/stable/24103532

Mudzielwana, R., Gitari, M. W., \& Ndungu, P. (2019) Performance evaluation of surfactant modified kaolin clay in As (III) and As(V) adsorption from groundwater: adsorption kinetics, isotherms and thermodynamics. Heliyon, 5, 1-7. Retrieved from https://doi.org/10.1016/j.heliyon.2019.e02756

Mustapha, S., Ndamitso, M. M., Abdulkareem, A. S., Tijani, J. O., Mohammed, A. K., \& Shuaib, D. T. (2019) Potential of using kaolin as a natural adsorbent for the removal of pollutants from tannery wastewater. Heliyon, 5, 1-9. Retrieved from https://doi.org/10.1016/j.heliyon.2019.e02923

N.M. Mahmoodi, M. Oveisi, A. (2019) Taghizadeh, M. Taghizadeh. Novel magnetic amine functionalized carbon nanotube/metal-organic framework nanocomposites: from green ultrasound-assisted synthesis to detailed selective pollutant removal model-ling from binary systems. J. Hazard. Mater. 368, 746-759. Retrieved from https://doi.org/10.1016/j.jhazmat.2019.01.107 
N.M. Mahmoodi. (2014) Synthesis of core-shell magnetic adsorbent nanoparticle and se-lectivity analysis for binary system dye removal, J. Ind. Eng. Chem., 20, 2050-2058. Retrieved from https://doi.org/10.1016/j.jiec.2013.09.030

Ogbu, I.C., Akpomie, K.G., Osunkunle, A.A., Eze, S.I. (2019) Sawdust-kaolinite composite as efficient sorbent for heavy metal ions. Bangladesh J. Sci. Ind. Res. 54, 99-110. Retrieved from https://doi.org/10.3329/bjsir.v54i1.40736

Syahida Farhan Azha, Mohammad Shahadat, Suzylawati Ismail, Syed Wazed Ali, Shaikh Ziauddin Ahammad. (2021) Prospect of clay-based flexible adsorbent coatings as cleaner production technique in wastewater treatment, challenges, and issues: A review. Journal of the Taiwan Institute of Chemical Engineers. 120, 178-206. Retrieved from https://doi.org/10.1016/j.jtice.2021.03.018

Q. Wu, R. You, Q. Lv, Y. Xu, W. You, Y. Yu. (2015) Efficient simultaneous removal of $\mathrm{Cu}(\mathrm{II})$ and Cr2072- from aqueous solution by a renewable amphoteric functionalized mesoporous silica. Chem. Eng. J. (Lausanne). 281, 491-501. Retrieved from https://doi.org/10.1016/j.cej.2015.07.019

Rao RAK, Ikram S, Uddin MK. (2014) Removal of Cd (II) from aqueous solution by exploring the biosorption characteristics of gaozaban (Onosma bracteatum). J Environ Chem Engg, 1, 1155-1164. Retrieved from https://doi.org/10.1016/j.jece.2014.04.008

Ridwan, Basuki Wirjosentono, Tamrin, R Siburian, Teuku Rihayat, Nurhanifa. (2018) Modification of PLA/PCL/Aceh's bentonite nanocomposites as biomedical materials, AIP Conference Proceedings. 2049, 1-6. Retrieved from https://doi.org/10.1063/1.5082413

Roosta, M., Ghaedi, M., Shokri, N., Daneshfar, A., Sahraei, R., Asghari, A. (2017) Optimization of the combined ultrasonic assisted/adsorption method forthe removal of malachite green by gold nanoparticles loaded onactivated carbon: Experimental design. Spectrochimica Acta Part A: Molecular and Biomolecular Spectroscopy. 118, 55-65. Retrieved from https://doi.org/10.1016/j.saa.2013.08.082

Safitri, Nelly, Syahputra, R, Putri, K, Rihayat, Teuku, Aidy, Nurhanifa, (2020) "Refining Citronella Oil (Cymbopogon Nardus L) by Utilizing Sunlight Using Solar Cells (Photovoltaics)," IOP Conference Series: Materials Science and Engineering,854, 012051. Retrieved from https://doi.org/10.1088/1757899X/854/1/012051

Saleh, A.T., Sari, A., Tuzen, M. (2016) Chitosan-modified vermiculite for As (III) adsorption from aqueous solution: equilibrium, thermodynamic and kinetic studies. J. Mol. Liq. 219, 937-945. Retrieved from https://doi.org/10.1016/j.molliq.2016.03.060

Santhosh, Ch, Velmurugan, V., Jacob, G., Jeong, S.K., Grace, A.N., Bhatnagar, A. (2016) Role of nanomaterials in water treatment applications : a review. Chem. Eng. J. 306, 1116 -1137. Retrieved from https://doi.org/10.1016/j.cej.2016.08.053

Santi, Raya, I., Zakir, M. (2014) The Adsorption of Pb (II) Ions on Activated Carbon from Rice Husk, Irradiated by Ultrasonic Waves:Kinetic and Thermodynamics Studies. Journal of Natural Sciences Research. 4, 4-9.

Singh, N., Gupta, S.K., (2016) Adsorption of heavy metals: a review. Int. J. Innov. Res. Sci. Eng. Technol., 5, 2267 -2281.

Sodeifian, G., Ali, S. (2018) Utilization of ultrasonic-assisted RESOLV (US-RESOLV) with polymeric stabilizers for production of amiodarone hydrochloride 
nanoparticles: Optimization of the process. Chem. Eng. Res. 142, 268-284. Retrieved from https://doi.org/10.1016/j.cherd.2018.12.020

Soltani, Darvishi Cheshmeh, Jorfi, S., Safari, M., Rajaei, M.-S., (2016) Enhanced sonocatalysis of textile wastewater using bentonite-supported $\mathrm{ZnO}$ nanoparticles: response surface methodological approach. J. Environ. Manag. 179, 47-57. Retrieved from https://doi.org/10.1016/j.jenvman.2016.05.001

Sun, K., Shi, Y., Chen, H., Wang, X., Li, Z. (2015) Extending surfactant-modified 2:1 clay minerals for the uptake and removal of diclofenac from water. J. Hazard Mater. 323, 567-574. Retrieved from https://doi.org/10.1016/j.jhazmat.2016.05.038

Suryani, Fitria, Rihayat, Teuku, Aidy, Nurhanifa, Hasnah, T, (2020) "Chitosan Modified Bio-Fibre Based Board as Antimicrobial and Anti-Crack Board," IOP Conference Series: Materials Science and Engineering, 854, 012050. Retrieved from https://doi.org/10.1088/1757-899X/854/1/012050

Suryani, Harry Agusnar, Basuki Wirjosentono, Teuku Rihayat, Nurhanifa. (2018) Thermal degradation of Aceh's bentonite reinforced poly lactic acid (PLA) based on renewable resources for packaging application. AIP Conference Proceedings. 2049, 1-5. Retrieved from https://doi.org/10.1063/1.5082445

Teuku Rihayat, Suryani, Satriananda, Ridwan, Nurhanifa, Alfian Putra, Nia Audina, Muhammad Yunus, Sariadi, Safari, Ramzi Jalal, Nani Siska Putri Khan, Saifuddin. (2018) Influence of coating polyurethane with mixture of bentonite and chitosan nanocomposites. AIP Conference Proceedings. 2049, 1-6. Retrieved from https://doi.org/10.1063/1.5082425

Teuku Rihayat, Suryani, Zaimahwati, Salmyah, Sariadi, Fitria, Satriananda, Alfian Putra, Zahra Fona, Juanda, Raudah, Aida Safitri, Mawaddah, Nurhanifa, Shafira Riskina and Wildan Syahputra. (2019). Composition on Essential Oil Extraction from Lemongrass Fragrant by Microwave Air Hydro Distillation Method to Perfume Dermatitis Production. Retrieved from https://doi.org/10.1088/1757-899X/506/1/012053

Tingting Zhang, Wei Wang, Yunliang Zhao, Haoyu Bai, Tong Wen, Shichang Kang, Guangsen Song, Shaoxian Song, Sridhar Komarneni, (2021) Removal of heavy metals and dyes by clay-based adsorbents: From natural clays to 1D and 2D nano-composites. Chemical Engineering Journal, 420, 127574. Retrieved from https://doi.org/10.1016/j.cej.2020.127574

Tripathi, A., Ranjan, M.R., (2015) Heavy metal removal from wastewater using low cost adsorbents. J. Bioremediat. Biodegr., 6, 315-320. Retrieved from https://doi.org/10.4172/2155-6199.1000315

Uddin, Mohammad Kashif. (2017) A Review on the Adsorption of Heavy Metals by Clay Minerals, with Special Focus on the Past Decade. Chemical Engineering Journal, 308, 438-62. Retrieved from https://doi.org/10.1016/j.cej.2016.09.029

Wenbo Wang, Wenting Zhao, Huan Zhang, Jiang Xu, Li Zong, Yuru Kang, Aiqin Wang. (2021) Mesoporous polymetallic silicate derived from naturally abundant mixed clay: A potential robust adsorbent for removal of cationic dye and antibiotic. Powder Technology. 390, 303-314. Retrieved from https://doi.org/10.1016/j.powtec.2021.05.090 